\title{
International Committee on Systematics of Prokaryotes. Subcommittee on the Taxonomy of Phototrophic Bacteria: Minutes of the closed online Meeting from 9-27 August 2021
}

Johannes F. Imhoff1,* and Annick Wilmotte ${ }^{2}$

\section{MINUTE 1. CALL TO ORDER}

The meeting was called to order by the chairman J.F. Imhoff on 9 August 2021 at 9:00 (CET).

\section{MINUTE 2. RECORD OF ATTENDANCE}

The following members participated in the meeting: L. Giovannetti (Florence, Italy), V. M. Gorlenko (Moscow, Russia), M. Gugger (Paris, France), J. F. Imhoff (Kiel, Germany), P. Anil Kumar (Chandigarh, India), A. Oren (Jerusalem, Israel), J. Overmann (Braunschweig, Germany), K. A. Palinska (Gdynia, Poland), Ch. Venkata Ramana (Hyderabad, India), R. Rippka (Paris, France), Ch. Sasikala (Hyderabad, India), A. Wilmotte (Liège, Belgium) and V. Yurkov (Winnipeg, Manitoba, Canada).

\section{MINUTE 3. APPROVAL OF AGENDA}

The agenda was approved.

\section{MINUTE 4. ACTUAL MEMBERSHIP}

L.Giovannetti (Florence, Italy), V. M. Gorlenko (Moscow, Russia), M. Gugger (Paris, France), J. F. Imhoff (Chairman, Kiel, Germany), J. Komárek (Třeboň, Czech Republic), P. Anil Kumar (Chandigarh, India), A. Oren (Jerusalem, Israel), J. Overmann (Braunschweig, Germany), K. A. Palinska (Gdynia, Poland), Ch. Venkata Ramana (Hyderabad, India), R. Rippka (Paris, France), Ch. Sasikala (Hyderabad, India), M. Tank (Braunschweig, Germany), S. Ventura (Florence, Italy). B. Whitton (Durham, England), A. Wilmotte (Secretary, Liège, Belgium) and V. Yurkov (Winnipeg, Manitoba, Canada).

\section{MINUTE 5. CHANGES IN MEMBERSHIP}

Several members, who with great expertise served this Subcommittee for many years, have resigned during the last few years. They include R. W. Castenholz, P. Caumette, F. Garcia-Pichel, M. Herdman and A. Hiraishi. The chairman and the members of this Subcommittee wished to express their sincere gratitude to all of them for their valuable contributions to our discussions. We are especially grateful for the highly valuable contributions of R. W. Castenholz, known to most as Dick, who died on 19 April 2018 at the age of 86 years. We will remember him not only for his many important contributions to this Subcommittee but also to science in general. His exceptional kindness and valuable advice, often requested by present and past Subcommittee members will also be missed.

\section{MINUTE 6. ELECTION OF NEW MEMBERS}

Several suggestions for election of new members of the Subcommittee were discussed and positive votes for all of the proposed candidates were received from the majority of the voting members. As a young scientist working for a number of years on the systematics of phototrophic purple bacteria and involved in the description of several new taxa, T. N. R. Srinivas (India) was elected as a new member. Among scientists active in work on the systematics and evolution of the Cyanobacteria, the suggestion

Author affiliations: 'GEOMAR Helmholtz Centre for Ocean Research, 24105 Kiel, Germany; ${ }^{2}$ InBios-Centre for Protein Engineering, University of Liège, 4000 Liège, Belgium.

*Correspondence: Johannes F. Imhoff, jimhoff@geomar.de

Keywords: Anoxygeniic phototrophic bacteria; cyanobacteria; taxonomy

Abbreviations: ICNP, International Code of Nomenclature of Prokaryotes; ICSP, International Committee on Systematics of Prokaryotes; ISPP,

International Symposium on Phototrophic Prokaryotes.

$005212 \odot 2022$ The Authors 
of four excellent candidates was discussed and all of them were approved as new candidates by the voting members. The newly elected members are M. F. Fiore (Brazil), T. Hauer (Czech Republic), R. Soo (Australia) and H. D. Laughinghouse (Florida, USA). All of them accepted their membership and expressed their great interest in supporting the activities of this Subcommittee. The chairman welcomed all new members and expressed wishes for fruitful future work in this Subcommittee.

\section{MINUTE 7. ELECTIONS OF OFFICERS}

The chairman informed the members about his desire to resign from the chair after 30 years. He proposed as his successor J. Overmann (DSMZ, Braunschweig, Germany), who has been an active member of the Subcommittee for many years. A. Wilmotte (Liège, Belgium) was proposed as secretary in continuation of her service over the past years. Apart from the abstention of the candidates themselves, both J. Overmann as new chairman and A. Wilmotte as secretary were elected unanimously. Both accepted their election. The chairman J. F. Imhoff congratulated them both and expressed best wishes for fruitful future work for the Subcommittee.

\section{MINUTE 8. REPORT OF THE CHAIRMAN}

The chairman recalled that the last meeting of this subcommittee was held in 2015 in Tübingen (04 August 2015) associated with the International Symposium on Phototrophic Prokaryotes (ISPP). There was no meeting of the subcommittee at the ISPP symposium in Vancouver 2018 because only a minority of the subcommittee members was attending this conference. Furthermore, the ISPP meeting in 2021 was cancelled due to the pandemic spread of Covid-19 and in consequence, the current meeting with communication via email correspondence was initiated.

The chairman drew attention of the subcommittee members to a recent publication publication by Oren et al.[1], reporting emendations of the International Code of Nomenclature of Prokaryotes (ICNP) concerning the status of the Cyanobacteria. There have been intensive discussions within the International Committee on Systematics of Prokaryotes (ICSP) on the question of how the Cyanobacteria should be treated under the ICNP, with the participation of members of this subcommittee in the discussions. Three proposals had been made [2-4]. They were discussed among members of the ICSP, the Judicial Commission and scientists interested in the systematics of the Cyanobacteria. A voting for adoption of one or the other of these proposals, with a voting period until 31 May 2021, resulted in clear favor of the proposal made by A. Oren [4]. We would like to thank A. Oren for his continued efforts and congratulate to this success.

Accordingly, the emendations of General Consideration 5 and Rules 18a, 24a and 30 of the ICNP were recently announced to resolve the status of the Cyanobacteria in prokaryotic nomenclature [1]. Those who were interested in the matter quite likely have followed the discussions and already noticed the results. Others may consult the publications given as references. Though these emendations resolve major key issues, further discussions on the consequences of the treatment of cyanobacterial nomenclature under the ICNP will certainly be required. Especially members of this subcommittee are expected to be involved and give their advice.

The chairman also recalled that a working group for preparing an approved list of species names of Cyanobacteria had been established in 2015 in Tübingen but up to date has not yet been active. He expressed his expectation that this group, including newly elected members of the subcommittee, would soon initiate activity.

The chairman informed about the progress made regarding a phylogenetic database on Cyanobacteria introduced to the subcommittee by M. Herdman at the last meeting (Minute 11 of the 2015 meeting in Tübingen). M. Herdman communicated a brief introduction of further progress to the chairman during this meeting and informed that the data are available on a public website created in 2017, and since then were repeatedly updated by inclusion of new data, with particular emphasis given on new taxa. The website http://cyanophylogeny.scienceontheweb.net/ covers different aspects of cyanobacterial phylogeny and now contains $>3500$ sequences in $16 \mathrm{~S}$ rRNA gene trees (showing levels of order, family, genus, species and strains). It also shows phylogenomic trees inferred from over $900 \mathrm{draft}$ and almost 200 complete genomes. These were heavily curated, since many genomic sequences are incomplete or seemingly chimeric and their inclusion would have seriously disturbed the tree topology. The chairman regarded this database as being of great value and an important aid for systematic and taxonomic studies of the Cyanobacteria. He highly recommended visiting and using this website.

\section{MINUTE 9. APPROVAL OF MINUTES FROM THE LAST MEETING}

The Minutes of the meeting held in 2015 in Tübingen were approved. 


\section{MINUTE 10. VARIA}

R. Rippka informed the Subcommittee about some serious problems arising from the description and designation of the holotype of the type species of Prochlorococcus, Prochlorococcus marinus under the ICN.

\section{MINUTE 11. CURRENT MEMBERSHIP}

The current members include all those listed under Minute 4 and in addition the newly elected members: M. F. Fiore (Brazil), T. Hauer (Czech Republic), H. D. Laughinghouse (Florida, USA), T. N. R. Srinivas (India) and R. Soo (Australia). The new Chairman is Jörg Overmann (Braunschweig, Germany).

\section{MINUTE 12. NEXT MEETING}

The next meeting of this Subcommittee is planned to be held during the International Symposium on Phototrophic Prokaryotes in Liverpool (England), which is scheduled for 21-25 August 2022.

\section{MINUTE 13. ADJOURNMENT}

The meeting was adjourned by the chairman J. F. Imhoff on 27 August 2021 at 17:00 (CET).

\section{References}

1. Oren A, Arahal DR, Rosselló-Móra R, Sutcliffe IC, Moore ERB. Emendation of general considerationGeneral Consideration 5 and rRules $18 \mathrm{a}, 24 \mathrm{a}$ and 30 of the international code of nomenclature of prokaryotesInternational Code of Nomenclature of Prokaryotes to resolve the status of the Cyanobacteria in the prokaryotic nomenclature. Int J Syst Evol Microbiol 2021;71:004939.

2. Oren A Garrity GM. Proposal to change general consideration 5 and principle 2 of the international code of nomenclature of prokaryotes. Int J Syst Evol Microbiol 2014;64: 309-310.
3. Pinevich AV. Proposal to consistently apply the international code of nomenclature of prokaryotes (ICNP) to names of the oxygenic photosynthetic bacteria (cyanobacteria), including those validly published under the international code of botanical nomenclature (ICBN)/ international Code of Nomenclature for algae, fungi and plants (ICN), and proposal to change Principle 2 of the ICNP. Int J Syst Evol Microbiol 2015;65:1070-1074.

4. Oren A. Three alternative proposals to emend the rules of the international code of nomenclature of prokaryotes to resolve the status of the Cyanobacteria in the prokaryotic nomenclature. Int J Syst Evol Microbiol 2020;70:4406-4408.

\section{Five reasons to publish your next article with a Microbiology Society journal \\ 1. The Microbiology Society is a not-for-profit organization. \\ 2. We offer fast and rigorous peer review - average time to first decision is 4-6 weeks. \\ 3. Our journals have a global readership with subscriptions held in research institutions around the world. \\ 4. $80 \%$ of our authors rate our submission process as 'excellent' or 'very good'. \\ 5. Your article will be published on an interactive journal platform with advanced metrics.}

Find out more and submit your article at microbiologyresearch.org. 